\begin{tabular}{|ccc|}
\hline & ANNALES INSTITUTI SLAVICI \\
& UnIVERSITATIS DEBRECENIENSIS & \\
SLAVICA XLIX & 2020 & DEBRECEN \\
\hline
\end{tabular}

Сергей Шульц

\title{
Б. СПИНОЗА, Н.В. ГОГОЛЬ, Ж. БОДРИЙЯР: К СПОРАМ О ТЕОЦЕНТРИЗМЕ И АНТРОПОЦЕНТРИЗМЕ
}

\author{
B. Spinoza, N.V. Gogol, J. Baudrillard: \\ On the Debate about Theocentrism and Anthropocentrism
}

\begin{abstract}
Interest in the problem of man, in the structure of the world and in its foundations is brought together, with all the difference, Spinoza, Gogol, Baudrillard. In the line-up of authors, three main attitudes are revealed. Spinoza: all that exists is theocentric; one must strive to comprehend God and His "extensions" (not creatures!) in the form of the world and man. Gogol: comic-romantic criticism regarding intramural irrationality with the author's aspiration for an eschatological perspective. Baudrillard: immersion in the pan-social as the only being, although it has (starting from the Renaissance) an empty foundation.

According to Spinoza, man, nature, the world, in general, everything in reality is an extension of God. Not "creation"! - it is a continuation, practically an integral part of God, some "doubles", although those with less "good." It turns out that God is not able to separate himself from what is around him, what is in the outside world and everything that is not He considers himself to be. Gogol, on the other hand, strove to portray man as really different in relation to God and at the same time capable of changing (the concept of "Dead Souls"). Isn't the "apocalypse of our time" outlined by Baudrillard? Its unchanging Marxist-Freudian jargon is intended only to serve the immediate intention of reforming social reality. The Baudrillard concept is marked by post- and neo-romantic scepticism regarding the nature of man and society. The extra-Marxist (and non-Freudian) in Baudrillard - his bet on "reversibility", on the "gift" (in the terminology of Moos and his followers) of the "gift", i.e. installation on a "symbolic exchange" between communicants in all spheres of existence. Thus, Baudrillard comes to recognize the linkage "modern / postmodern" and to recognize the benefits of modernity. The transformation of "dead souls" is a path that Gogol also thought about realizing on different grounds and which opposes the complacency of Spinozist machines.
\end{abstract}

Keywords: Spinoza, Gogol, Baudrillard, theocentrism, anthropocentrism

Актуализация теологической и антропологической проблематики, столь характерная для сочинений Спинозы, Гоголя, Бодрийяра, заставляет сблизить трех авторов. Не всё в их текстах проговорено «прямо» ${ }^{1}$, но фактура их работ выводит к скрытым семантическим контекстам, способствующим приращению смысла. Задача данной работы - герменевтическая дешифровка скрытых смыслов и скрытой генеалогии наследия Спинозы, Гоголя, Бодрийяра. Безусловно, любой разговор об авторах такого ранга по определению не может

1 Например, теологическая проблематика у Бодрийяра. 
претендовать на то, чтобы искать у них какие-либо «ошибки». Однако рассмотрение их в качестве участников современного культурфилософского и социально-политического диалога - добавим: в качестве непосредственных участников - в полемических целях позволяет не избегать острых углов.

Подчеркивая включенность Спинозы, Гоголя, Бодрийяра в современность, нельзя не затронуть вопрос о роли в ситуации нынешнего мира связки модернизм/постмодернизм. Значимость данной связки убедительно показана Ю. Хабермасом, который справедливо отдавал предпочтение модерну ${ }^{2}$ как гаранту исторического движения, гаранту новизны и позитивных изменений [ХАБЕРМАС 2008]. Далее мы попытаемся продемонстрировать, хотя бы пунктирно, связь Спинозы с зарождением постмодерна, а также значение Гоголя и Бодрийяра для утверждения модернистской установки.

Свидетельств чтения Гоголем философских сочинений немного, так же немного упоминаний философов в его текстах (имени Спинозы нет). Однако необходимо учитывать, что рецепция мыслителя началась в России еще в первой половине XVIII в. Ф. Прокоповичем. Затем А.Н. Радищев писал о Спинозе как о философе, который «ощущал» «над собою власть», превышающую человека «власть всеотца», «источника всех сил» [РАДиЩЕВ 2001: 30].

Радищевская оценка акцентирует в мире Спинозы идею всемогущего и благого Бога - идею, близкую христианской доктрине. В.С. Соловьев признавался, что в ранний, славянофильский период своего философского творчества он считал Спинозу близким православию: «...православная формула $<\ldots>$ состоит в том, что Христос страдал, умер и воскрес не по божеству, а по человечеству» [СолОвьЕв 2002: 138]. Соловьев подразумевает, что в восточном христианстве отрицается догмат filioque (о том, что Святой Дух исходит и от Сына): отсюда выдвижение наперед первой ипостаси Троицы. Вторая же ипостась предстает в православии не в столь могущественном виде по сравнению с католицизмом ${ }^{3}$.

Однако необходимо во многом возразить Соловьеву: само по себе отрицание filioque еще не сближает православие и спинозизм. К тому же соловьевское сопоставление носит преимущественно эмоциональный характер, его направляют импульсы, непосредственно не относящиеся к теологии, а «попутные».

В первой половине XIX в. к наследию Спинозы обращались, в том числе, отдельные представители окружения Гоголя - любомудры (прямые отклики у В.Ф. Одоевского), а также П.Я. Чаадаев [КАУФМАН 2005: 321-324, 325-328]. Кроме того, Гоголь хорошо знал богословскую литературу [ВОРОПАЕВ 2002], а та неизменно сопряжена с метафизикой. Гоголь, фиксирующий в своем творчестве иррационализм ситуации современного ему мира и комический абсурд как зазор между мыслью об идеале и реальностью ${ }^{4}$, не был утопистом, но он и не оправдывал целиком существующий миропорядок, в отличие от Спинозы или Гегеля. Художественная мысль Гоголя близка установке христианской

2 Возводя его генезис к XVIII в.: [ХАБЕРмАС 2005].

3 Где догмат filioque формально зафиксирован.

4 Именно так А. Камю в XX в. сформулировал принцип абсурда. 
религии и теологии на смысловое и, вместе с тем, действительное преображение жизненно-исторического мира.

Контекст Спинозы - постренессансный и зачинающий ряд Нового времени, ряд предпросветительский. Спиноза, переработавший ренессансный пантеизм (от которого, впрочем, в спинозизме осталось скорее сходство отдельных концептов) и ренессансный гуманизм, а также рационалистическую философию Декарта, оперирует сугубо логицистскими и механицистскими формулировками и аргументами ${ }^{5}$. Словно о Спинозе замечание Гоголя из его набросков к «Комед<ии>: «Толкует по-своему, вроде метафизическое математическим» [ГОГОЛЬ 2009-2010 т.7: 130].

Спиноза теоцентричен. И Гоголь выстраивает модель физического и исторического космоса, а также непосредственно социума в рамках теоцентризма. Однако принципы понимания двумя авторами Бога и мироздания различны.

Во второй половине XX в. Ж. Делез и Ф. Гваттари назвали Спинозу «королем философов» за якобы отсутствие у Спинозы претензий на «мудрость» [ДЕЛЁ3 2001; ДЕЛЁ3 - ГВАТТАРИ 2009], хотя Спиноза от таких претензий вовсе не отказывался. Следы спинозизма, но с обратным знаком, заметны у Бодрийяра. Бодрийяр констатировал наступление эры симулякров - ложных подобий при отсутствии их источника (референта). Симулякры, тем самым, укоренены в Ничто. Референт симулякров - не только разного рода предметность, но и мир знаков, отношений, понятий. У Бодрийяра налицо рудименты апофатической трактовки Бога как Ничто. В спинозизме единственная «субстанция» - Бог, а у французского мыслителя функции такого рода выполняет небожественное Ничто. С приведенными фактами связан также бодрийяровский концепт «гиперреальность», означающий сплетение действительных фактов с домыслами и фантазмами.

Интерес к устройству мира и к его основаниям, а также попытки найти принципы приемлемого функционирования социума сближают Спинозу, Гоголя, Бодрийяра. В выстраиваемом ряду налицо три основные установки. Спиноза: всё сущее теоцентрично, надо стремиться к постижению Бога и Его «продолжений» (не порождений!) в виде мира и человека. Гоголь: комическо-романтический критицизм в отношении внутримировой иррациональности при устремлении автора к эсхатологической перспективе. Бодрийяр: преимущественное внимание к пансоциальному (которое, по мнению Бодрийяра, с эпохи Ренессанса имеет «пустую» основу, т.е. опирается на Ничто - на смысловые провалы в оценке субъектами различных социально-политических моментов); поиск диалога с симулякрами для «излечения» пансоциального, возвращения ему исконного статуса многосторонней межличностной коммуникации 6 .

По-своему пытавшийся синтезировать ветхозаветное и новозаветное послания с арабской мыслью, Спиноза превращает философию в теологию

5 Отсюда его «геометрический метод». Ключевой текст позднего Э. Гуссерля «Начало геометрии» явно полемичен в отношении формулировки «геометрический метод» и, разумеется, самой процедуры, таким методом подразумеваемой.

6 Межличностной коммуникации в самом широком значении, идентичном используемом Ю. Хабермасом. 
с установкой на постижение Бога как «высшего блага». Он следует давней традиции различения «природы созидающей» и «природы созидаемой». В его «Этике» такому различению соответствуют два способа понимания вещей - реальный (разумный) и модальный (в воображении). Однако «природа создаваемая» (модус воображения) выступает для Спинозы определенным продолжением «природы созидающей» (Бога), поскольку Бог в спинозизме составляет единственную субстанцию. Пребывание Бога в вечности, а «природы созданной» (мира и человека) во времени не противопоставляет их друг другу, поскольку, согласно Спинозе, время также создано Богом, подобно воображению.

Однако Бог Спинозы - лишь прием для тотального оправдания всего наличного, как оно есть здесь и сейчас, а спинозовская теология оборачивается антропологией психологического/психологистического/механицистского комфорта «я» (субъекта). Несмотря на то, что у Спинозы задано понятие бесконечного мышления, в том полностью отсутствует момент историзма ${ }^{7}$. В своих конструкциях Спиноза не выходит за пределы синхронии. Его «бесконечное мышление» ограничено тем, что «я» наблюдает вокруг себя в данный момент. Исток построений Спинозы - долженствование, а не фактичность. Спинозовское долженствование состоит в том, чтобы обеспечить для «я» максимум внешнего и внутреннего комфорта: под эту идею и подбираются все доказательства. Поэтому Спиноза «набрасывает» на мир «сетку» заранее подобранных искусственных оценок и искусственных аргументов. Он делает существенный шаг к тому, что уже в наше время назвали постправдой.

Постправда - манипулирование, оправдывающее свои меркантильные цели якобы высокими и запутывающее не только окружающих, но и самого себя ${ }^{8}$. Спиноза дискредитировал понятие цели. В качестве мотива своего философствования Спиноза выдвинул мирооправдание - хотя реальной подоплекой было его личное оправдание. Здесь почти та же логика, что и в ренессансном концепте гуманизма ${ }^{9}$, а затем в концепте постмодерна.

Все декларации Спинозы - в выражениях следования «благой цели», например: «Конечная цель заключается не в том, чтобы господствовать и держать людей в страхе, подчиняя их власти другого, но, наоборот, в том, чтобы каждого освободить от страха, дабы он жил в безопасности, насколько это возможно» [СПинОЗА 1991: 295]. Л.И. Шестов считал, что весь «Теолого-политический трактат» посвящен «доказательству той мысли, что Библия вовсе и не стремится

7 Вопреки мнению В.С. Соловьева [Соловьев 2002].

8 Уже Сервантес в «Дон Кихоте» при изображении разнородных реакций окружающих на поступки Дон Кихота показал сущность т.н. «постправды»: насмешники отдают себе отчет в том, кто таков Дон Кихот, но запутывают и его, и всех остальных, и самих себя.

9 У Канта понятие цели несет печать спинозистской двойственности. Кант призвал рассматривать человека в качестве цели, но ведь нет цели вообще, цели чистой в себе вообще. Как методы бывают негодными, так негодными некоторые представляют себе цели. Низкие средства уже моделируют низкую цель, даже при наличии больших надежд на «благое» дело впереди: в этом, например, коллизия самообмана Раскольникова в «Преступлении и наказании» Ф.М. Достоевского [КАРяКИН 1976]. 
научить человека истине, что ее задача - только нравственная: научить человека жить в добре...» [ШеСтов 1990: 253]. Для Спинозы «в добре» означает: в субъективистском психологистическом комфорте «я», причем отдельно взятого «я».

Согласно Спинозе, человек, природа, мир, вообще всё в реальности - продолжение Бога. Не «творение»! - именно продолжение, практически составная часть Бога. Выходит, что Бог не в состоянии отделить себя от того, что вокруг него, что во внешнем мире. Получается, спинозовский Бог всё, что не Он, считает собою. Повсюду только и есть, что Первосубъект (единственная субстанция) и его «двойники», хотя те с меньшим количеством «блага» (к тому же ведь они «воображаемые» - почти что симулякры, в терминологии Бодрийяра).

Будто бы похоже на теологическую систему Фомы Аквинского, томизм, но радикальная разница в том, что у св. Фомы Творец и творение взаимоотделены, каждый из них - свободен. По поводу Бога Спинозы вспоминается фраза Хлестакова из «Ревизора»: «Я везде, везде!» [ГоГОЛь 2009-2010 т.4: 258]. «Кругом возможно Бог» - таково амбивалентное название поэмы обэриута А.И. Введенского, наследника Гоголя. Где в названии смысловое ударение: возможно Бог? Или возможно Бог? Или возможно кругом Бог? Ирония Введенского в адрес именно Спинозы очевидна.

Вслед за Монтенем и Шекспиром Спиноза утверждает, что добро и зло не в самих вещах, а в отношении к ним самих людей. Но, в отличие от ренессансных авторов, у Спинозы этот вывод следует не из идеи смыслового порождения/преображения мира, а из механицистских оценок.

Отсюда же спинозовский тезис о том, что дьявола не существует, поскольку кругом - Бог, высшее благо. Но если вокруг Первосубъекта в принципе нет реального другого (других), потенциально способного осуществить ответный диалогический жест, то Бог - в «вакууме». От продолжений-двойников ничего услышать и узнать нельзя: ведь это не реальные другие в их другости; к тому же продолжения-двойники фаталистически заданы Первосубъектом изначально.

Противник всякой абстрактности, Гегель, тем не менее увидел «величие склада мыслей Спинозы <.. > в том, что он мог отказаться от всего определенного, особенного и держаться лишь единого, почитать лишь это единое» [ГЕГЕЛЬ 1994: 348]. И далее: «Что же касается перехода Спинозы к отдельным вещам и, в особенности, к самосознанию, к свободе «я», то он < .. $>$ больше сводит все ограниченности к субстанции, чем фиксирует единичное» [ГЕГЕЛЬ 1994: 357]. Однако ведь свое единое Спиноза выдает за особенное, конкретное, чем совершается подмена. Впрочем, у Спинозы реально вообще нет единого, поскольку центр и части рассмотрены сразу однопорядковыми, взаимопринадлежащими. Получается, словно в ключе А. Арто, некое «тело без органов»: одно сплошное единство без составных элементов.

Спиноза выводит дух из природы: дух должен «наиболее отражать природу», т.е. «объективно иметь и ее сущность, и порядок, и единство» [СПинОЗА 1998б: 320]. Тем самым Спиноза вроде бы пытается вдохнуть в механицистскую «природу» Декарта «дух» и «душу», однако в итоге дух предстает 
у Спинозы чем-то полностью подчиненным «природе». Разве это пантеизм? Тут первенство не духа (не Бога), а непосредственно самого природного.

В «Вечерах на хуторе близ Диканьки» Гоголь, в противовес узкому рационализму, изобразил «душу» природы в качестве художественного проявления души мира: налицо близость «эстетическому пантеизму» ${ }^{10}$ Шеллинга, но не спинозовскому псевдопантеизму. Вопреки Спинозе, черт у Гоголя реален, проделки черта (хаос в мироздании) реальны. Однако в «Вечерах...» черт смешон, тем самым развенчан. У позднего Гоголя черт приобретет более страшный вид, о чем есть запись в его предсмертной молитве: «Помилуй меня, грешного, прости, Господи! Свяжи вновь сатану таинственною силой неисповедимого Креста!» [ГОГОЛь 2009-2010 т.6: 414].

По мнению В.В. Бычкова, Гоголь «...остро ощущает, что его творчеством руководит Бог» [Бычков 2007: 11]. Однако Гоголь боялся искушения. У позднего Гоголя выстраивалась идея творчества как бы на равных с Богом, словно на равных. Уже этого тезиса было для него достаточно для предъявления себе незаслуженных упреков, в том числе «в потакании» черту.

Согласно замечанию Ю.М. Лотмана: «Гоголь верил в то, что он не “изображает”, а творит мир» [ЛоТМАН 1996: 15]. Однако коннотации этого «творит» у Гоголя весьма двусмысленны, на грани с буквалистским значением. В XX в. П.А. Флоренский напоминал, что для христианина Бог - художник, творящий мир как свое художественное произведение, что человек-художник в своем искусстве уподобляется Богу [ФЛОРЕНСКИй 2000: 18-19]. Гоголь расширил рамки указанного уподобления...

Спиноза считал, что у человека нет свободы воли и свободы выбора: поскольку человек якобы изначально «в Боге», то нечего и выбирать. Чтобы смягчить вытекающую отсюда сугубую каузальность, Спиноза допустил, что при всей фатальности человек способен что-то решить сам и даже способен «совершенствоваться». Но данная уступка малоубедительна. В мире Спинозы человек так и остается «игрушкой» в руках Бога (формулировка позднего Платона), «марионеткой» (образ Г. фон Клейста), принужденной лишь следовать указаниям абсолютной субстанции.

В финале ранней гоголевской повести «Сорочинская ярмарка» изображены герои-автоматы, но, вопреки Спинозе, лишенные всякой «божественности»: «Странное неизъяснимое чувство овладело бы зрителем, при виде, как от одного удара смычком музыканта $<\ldots>>$ всё обратилось, волею и неволею, к единству и перешло в согласие. <..> Но еще страннее, еще неразгаданнее чувство пробудилось бы в глубине души при взгляде на старушек, на ветхих лицах которых веяло равнодушие могилы, толкавшихся между новым, смеющимся, живым человеком. < .. > даже без детской радости, без искры сочувствия, которых один хмель только, как механик своего безжизненного автомата, заставляет делать что-то подобное человеческому, они тихо покачивали охмелевшими головами, подтанцывая за веселящимся народом...» [ГОГОЛь 2009-2010 т.1: 111].

10 Термин П.П. Гайденко. 
Обратив внимание на механизированный образ танцующих старушек, Ю.В. Манн связал его с отступлением от карнавального начала [МАнН 1988: 5-38]. Точнее, однако, рассуждать о романтическом варьировании карнавальности. Гоголь метит в спинозизм, распространяющий длань абсолютной субстанции на всё мироздание, вот почему автоматизированы танцующие. В идеале Гоголь видит свободу воли в каждом - прежде всего в способности субъекта внутренне развиваться и меняться (на этом основан замысел «Мертвых душ»). В целом это предмодернистская/модернистская установка ${ }^{11}$.

Представления Спинозы о Боге взяты из его собственных представлений о человеке, в данном случае - о самом себе. В спинозовской концепции проступают контуры образа человека до грехопадения и (руссоистского) «безгрешного» «естественного человека». Отсюда у Спинозы элементы теомании: это когда субъект (в данном случае сам Спиноза) считает себя Богом, совершая подмену понятий и фактов («постправда»). Уже изначально и тем более в итоге Спиноза подменяет теологию антропологией. Грубо говоря, подменяет идеей обустройства мира без Бога, хотя и с именем Бога на устах.

В гоголевской «Записной книжке 1846-1850 гг.»есть примечательное высказывание: «Неизьяснимое вечернее блистанье $<\ldots>$ по них разметан $<$ Н $>$ ых злаков. Погасанье лучей и дым от хат легкими струями к небу нес $<$ ется?>. Как осмелился позабыть тебя человек. О, да будет проклят, кто научил людей покинуть простоту для просвещенья. Заплатил страданьями и тяжким и подлым бессилием» [ГОГОль 2009-2010 т.9: 706]. В начале цитаты через сельские виды-пейзажи обрисована картина некоего земного рая. Те выступают символом/аллегорией потерянного рая. Утеря «простоты» объясняется тягой к «просвещенью», явно не сводимого Гоголем к XVIII в. В гоголевской цитате дело идет о глобальной ситуации потери первочеловеком (почти «естественным человеком») «простоты», хотя Гоголь закономерно различает статус человека до и после грехопадения: после грехопадения «естественность» в человеке уже невозможна.

Элементы концепции «естественного человека» распространяются в мире Гоголя в основном на обитателей идиллий - таков помещик Петух в позднейшей редакции второго тома «Мертвых душ»: «...вместе с рыбою запутался как-то круглый человек, такой же меры в вышину, как и в толщину, точный арбуз или бочонок» [ГОГОЛь 2009-2010 т.5: 408]. По замечанию А.Х. Гольденберга, Гоголь «своей иронией <..> разрушает мир Петуха» [ГОЛЬДЕНБЕРГ 2012: 81]. Гоголевская ирония подвергает сомнению идею «естественности»«божественности» человека, каким тот стал, оказавшись в ситуации после грехопадения - вот с того момента и в перспективе до Страшного суда.

Спинозой в определенной мере предвосхищена гоголевская топика «мертвых душ». Поднимая вопрос о том, в каком значении человеческая душа смертна, Спиноза умозаключает, что Бог может создать, может и разрушить; каждая вещь непрерывно продолжает твориться Богом. Философ имеет в виду произвол, каприз Бога, что вступает в некий конфликт со спинозовской же

11 Подробнее о гоголевском предвосхищении модернизма см.: [БЕЛЬй 1996; МАнН 2019; Шульц 2018]. 
фатальностью и детерминизмом. Заданная Спинозой (хотя не его по факту рождения) идея всё продолжающегося творения мира реально заменена у философа идеей непрерывного дления Богом себя же самого. Человеку, вопреки внешним спинозовским декларациям, вовсе не надо «совершенствоваться» спинозистский Бог сам доделает свои автоматы.

В гоголевском образе «мертвых душ» концептуализированы фактически все люди всех стран, в перспективе их личной и общей эсхатологии. Искры божественности («живости») Гоголь искал у всех людей и смог найти только в художнике и в подвижнике, согласно писателю, равно подражающих Христу. С подвижником поздним Гоголем отождествляется также рачительный помещик. В первом томе «Мертвых душ» намечен сложный образ «прирожденных страстей», которые самим Богом даны человеку для совершения незримых путей к благу. Гоголь - крайнее опровержение спинозизма.

Спиноза перевернул аристотелевское представление о том, что философия начинается с удивления, предложив ничему не удивляться, в том числе отсюда спинозовское отрицание смеха. Ведь смех так или иначе восходит к некоему «удивлению» («пораженности»). С точки зрения Спинозы, «Насмешка и шутка зависят от ложного мнения и обнаруживают в насмешнике и шутнике несовершенство» [СПинОЗА 1998а: 89]. В процитированном высказывании перевернуто аристотелевское представление о необходимой доле «плохого» в объекте для провоцирования у субъекта насмешки. Спиноза считает, что, напротив, несовершенство - в самом только шутнике. По поводу носителей такого мнения Бахтин употреблял термин «агеласт», т.е. официозный противник смеха.

В следующих словах Спинозы будто бы намечен выход к идее постижения Бога через «интуитивно-созерцательное» начало (М. Шелер): «Бог для своего проявления людям не нуждается ни в словах, ни в чудесах, ни в сотворенных вещах, а только в себе самом» [СПинОЗА 1998а: 119]. Однако реально Спиноза все сводит к познанию Богом себя же: налицо концепция Первосубъекта, существующего только для себя. Вместо «интуитивно-созерцательного» начала у Спинозы дело идет о неких личных «догадках» каждого, которые тот должен возводить к Богу - концепция, близкая бодрийяровскому концепту гиперреальности, смешивающей реальное и вымышленное (домысленное).

Против Бога Спинозы явно направлено высказывание Н.А. Бердяева: «Бог без человека, Бог бесчеловечный был бы сатаной» [БЕРДЯЕВ 1990] ${ }^{12}$. Монистический Бог Спинозы - Бог сверхпорядка, энтропийный Бог, тем самым это Бог хаоса, внешнего и внутреннего (в человеческой душе). В тисках так понятого Бога омертвляется даже самое живое.

М. Шелер противопоставил Спинозу и Фихте как «Созерцателя» - «морально настроенному, нацеленному на улучшение и изменение мира Деятелю» [ШЕЛЕР 1994: 67]. Оспаривая правомерность обозначения Спинозы «Созерцателем»,

12 Хорошо известно изречение, что смерть Бога влечет за собой также смерть человека. В развитие этой мысли М. Фуко во второй половине ХХ в. констатировал, что ныне исчезает идея человека и сам человек. 
нельзя не отнести характеристику, данную Фихте («Созерцателю»), к Гоголю, думавшему о смысловом и действительном преображении мира в эсхатологической перспективе.

Разве не «апокалипсис нашего времени» ${ }^{13}$ обрисовал Бодрийяр? Его неизменный марксистско-фрейдистский жаргон призван лишь обслуживать непосредственную интенцию реформирования социальной реальности. В бодрийяровской концепции заметен пост- и неоромантический скепсис в отношении природы человека и социума, скепсис, сближающий его с абсурдизмом и иррационализмом Э.Т.А. Гофмана (концепция бездушных автоматов-людей, заменяющих живое начало или воплощенная в образе Крошки Цахеса идея законного права на приписывание себе достижений других, т.е. идея права на постправду), А. Шамиссо, Ф. Ницше, Е.Л. Шварца (у трех последних - концепция главенства тени над ее носителем), а также Гоголя, Ф. Кафки или Э. Ионеско.

К философии романтизма (преимущественно позднего в лице Ницше) и модернизма [ХАБЕРМАС 2008] возводим также парадоксальный историзм Бодрийяра, заключающийся в поиске им генеалогии эры симулякров. Точку отсчета генеалогии Бодрийяр обнаруживает в Возрождении. Философ полагает, что «недобросовестная» подмена знаком реальности «со времен Ренессанса подтачивает изнутри всю нашу живопись» [БодРИйяР 1994 с.350]. Если «пространство Ренессанса» «упорядочивалось» «убегающей вглубь линией перспективы», то в нынешнем мире «обманки» (специальный бодрийяровский термин) «эффект перспективы так или иначе проецируется вперед» [БОДРИйяР 1994]: «Объекты здесь < .. > сами “обманывают" глаз < ..> - не потому, что они внушают веру в реальный мир, которого не существует, но потому, что они переигрывают и опрокидывают привилегированную позицию взгляда». С Ренессанса берет начало «прочесывающий <..> глаз», «паноптический взгляд», т.е взгляд-господство над объектом. Теперь же «самим вам ничего не увидеть, это вещи вас видят, они не убегают перед вами в перспективу (как в линейной перспективе ренессансной живописи. - С.Ш.), они несутся вам навстречу» [БОДРИЙяР 1994]. «Обманка» становится «ироническим симулякром» Ренессанса [БодРийяр 1994: 351], т.е. заведомо ложным, глумливым подобием того, что само дало начало ошибочному, согласно Бодрийяру, движению, - подобием Возрождения ${ }^{14}$.

Критически констатируя неразличение тела и лица в современном мире, Бодрийяр прямо использует понятие «ничто»: «Лицо, все равно какое, оказывается неуместным, поскольку оно ломает непристойность (современности. С.Ш.) и восстанавливает смысл там, где, в исступлении секса и головокружительной круговерти ничто, все нацелено на его (лица. - С.Ш.) упразднение»

13 Так назвал свою книгу о событиях октября 1917 г. В.В. Розанов.

14 Нельзя не заметить сходство взглядов на Ренессанс у Бодрийяра и П.А. Флоренского (см.: [ФЛОРЕНСКий 2000]). Однако нельзя не противопоставить ренессансной живописи, как ее поняли Бодрийяр и Флоренский, ренессансную литературу, где эффектов иллюзионизма и «паноптизма» почти нет, зато присутствует установка на панфилософскую рефлексию, высокий вымысел, высокую занимательность. 
[там же: 340]. Критика Бодрийяром «упразднения» лица и вообще человеческого в человеке корреспондирует гоголевским метафизическим описаниям псевдолиц - начиная с персонажей «Ивана Федоровича Шпоньки и его тетушки» до «Носа», «Шинели» (ср. образ «значительного лица») и «Мертвых душ». В «Носе» разрушение человеческого лица и наделение одной его части прерогативами целого (когда пропавший нос становится господином Носом, самостоятельным субъектом) трактовано Гоголем как «растерзание» (Н.А. Бердяев) образа и подобия Божьего в человеке. Хотя Бодрийяр теологического языка избегает, его оценки по содержанию не столь от него далеки.

Благодаря тому, Спиноза воспринимал онтологический статус вещей мира лишь в виде элементов («модусов») Первосубъекта, уже в его философии заложен генезис теории симулякров Ж. Бодрийяра. Однако Бодрийяр отнесся к «двойникам» спинозовского Бога гораздо критичнее самого Спинозы. Бодрийяровские симулякры - это словно те же двойники Бога, что и у Спинозы, но у философа XX в. их существование конституируется в отрицательном регистре, дано в виде фиктивного, фантомного. Философия Бодрийяра - это спинозизм, доведенный до своего логического отрицания, демистифицированный (вместо Бога - Ничто в качестве основы всего).

Бодрийяровский пафос похож на апофатику, т.е. на отрицательное познание Бога, на отрицательную онтологию. По замечанию О.А. Печенкиной, понятие симулякра приобретает у Бодрийяра этико-онтологический характер [ПеченкинА 2006: 6]. В отличие от Ничто Ж.П. Сартра, Ничто Бодрийяра - не трагическое, а пессимистическое, что более соответствует современной ситуации. Бодрирйяровское пансоциальное, потерявшее в современности свою основу, взыскует ее в виде обретения «социального пантеизма» (подлинной общественной коммуникации).

Бодрийяр констатирует: «Победила другая стадия ценности, стадия полной относительности, всеобщей подстановки, комбинаторики и симуляции. Симуляции в том смысле, что теперь все знаки обмениваются друг на друга, но не обмениваются больше ни на что реальное...» [БОДРИЙяР 2006: 52]. Под отказом от детерминированности Бодрийяр имеет в виду лишение смыслопорождающего акта реальной основы и реального наполнения.

Гоголевский мир наполнен фантомами - от случайно забредших в хату «не тех» гостей («Вечера...») до панночки, «раздвоенной» то на молодую красавицу, то на старуху («Вий»), от ложного ревизора (Хлестаков) до мертвых душ, от мнимого жениха (Подколесин в «Женитьбе») до мнимого карточного гения (Ихарев в «Игроках»). Каков онтологический статус этих персон в гоголевском мире? Они словно не дорастают до статуса реальности... ${ }^{15}$

Наперекор идее «высшего блага» в спинозистском варианте Бодрийяр строит свою концепцию «прозрачности Зла», позволяющую избежать ложного отождествления заведомо нетождественного, вообще подмен. Бодрийяровская

15 Исследования мотивов фантомности, пустоты, отсутствия и Ничто в мире Гоголя см. в сб.: [SPIEKER 1999]. 
критическая концепция «гиперреальности» направлена против сцепления реального и фантазматического, в том числе против спинозистского принципа тождества Бога и его «продолжений». Поэтому, пожалуй, Бодрийяр трезвее остальных описал состояние постмодерна. Мир постмодерна - фантомный и фиктивный мир, в котором всё уже якобы давно произошло, все якобы уже давно сказано, показано, а нового нет и уже никогда не будет. «Гиперреальность» бессильна вместить в себя действительные вещи мира.

Бодрийяр считал, что после Возрождения «Социальная история человечества становится историей вытеснения смерти», т.е. одного из естественных состояний всего живого, и что вслед за мертвыми из социального пространства последовательно изгоняются дикари, сумасшедшие, дети, старики, необразованные, бедняки... [БОДРИЙЯР 2006; ГАРАДЖА 1991: 44]. В последнем случае дело идет о неких «париях общества», начиная с дикаря- «естественного человека», не вписывающегося в просчитанные правила наличного социума, и заканчивая социально ущемленными слоями.

Бодрийяр призывает к диалогу с симулякрами - диалогу, не могущему, заметим, не оказаться мнимым. Подобный призыв - уступка постмодерну, изымающая симулякры из их контекста, из многостороннего хронотопа существования. Тем более сомненителен бодрийяровский императив первенства объекта (симулякров) над субъектом.

Внемарксистское и внефрейдистское в Бодрийяре - его ставка на обратимость, т.е. на «отдаривание» дара. Обратимость подразумевает способность к изменениям, обновлению, а «отдаривание дара» - императив символического обмена между коммуникантами во всех сферах жизненно-исторического мира. Это модернистская установка, в наши дни лишь с нею возможно вступление в подлинный социально-политический диалог, который «кладет конец линейности времени, <...> экономическому обмену, накоплению и власти» [ГАРАДЖА 1991: 44-45]. Тем самым Бодрийяр приходит к расшатыванию связки «модерн/постмодерн» ${ }^{16}$, утверждая преимущество модерна.

16 Роль для современности связки «модерн/постмодерн» убедительно показана Ю. Хабермасом. 


\section{Литература}

БЕЛЫЙ 1996: Белый, Андрей. Мастерство Гоголя. [2-е изд.] Москва: Книговек, 310-339

БЕРДяЕВ 1990: Бердяев, Н.А. <Афоризмы> // Литературная газета. 18 июля 1990. №29. С.12.

БодРийяр 1994: Бодрийяр, Ж. О совращении // Ad marginem'93. Ежегодник Лаборатории постклассических исследований ИФ РАН. Москва: Ad marginem, 324-353. (пер. с фр. Зенкина, С.Н.)

БодРИйяр 2006: Бодрийяр, Ж. Символический обмен и смерть. Москва: Добросвет, С.389. (пер. с фр.)

Бычков 2007: Бычков, В.В. Русская теургическая эстетика. Москва: Ладомир.

ВоРОПАЕв 2002: Воропаев, В.А. Гоголь над страницами духовных книг. Москва: Макариевский фонд.

ГАРАДЖА 1991: Гараджа, А.В. Бодрийяр Ж. // Современная западная философия. Словарь. Москва: Политиздат, 44-45.

ГЕГЕЛЬ 1994: Гегель, Г.В.Ф. Лекции по истории философии. Санкт-Петербург: Наука.

ГоГоль 2009-2010: Гоголь, Н.В. Полн. собр. соч. и писем: в 17 т. Москва; Киев: Издательство Московской Патриархии.

ГольДЕНБЕРГ 2012: Гольденберг, А.Х. Архетипы в поэтике Н.В. Гоголя. 2-е изд. Москва: Флинта.

ДЕлЁз 2001: Делёз, Ж. Спиноза // Делёз Ж. Эмпиризм и субъективность: опыт о человеческой природе по Юму. Критическая философия Канта: учение о способностях. Бергсонизм. Спиноза. Москва: ПЕР СЭ, 325-444. (Пер с фр.)

ДЕЛЁ3 - ГвАТТАРИ 2009: Делёз, Ж., Гваттари, Ф. Что такое философия? Москва. (пер. с фр. Зенкина, С.Н.)

КАРЯКИН 1976: Карякин, Ю.Ф. Самообман Раскольникова. Роман Ф.М. Достоевского "Преступление и наказание". Москва: Художеств. лит.

КАУФМАН 2005: Кауфман, И.С. Философия Спинозы в России. Первая часть. 1774 1884 // Историко-философский ежегодник. 2004. Москва: Наука, 312-344.

ЛотмАН 1996: Лотман, Ю.М. О «реализме» Гоголя // Труды по русскому и славянскому литературоведению. Новая серия. Вып. II. Тарту, 11-35.

МАнн 1988: Манн, Ю.В. Поэтика Гоголя. 2-е изд. Москва, 413.

МАнн 2019: Манн, Ю.В. Поэтика Гоголя как предвестие модернизма (заметки) // Гоголь и пути развития русской литературы. Восемнадцатые Гоголевские чтения. Москва; Новосибирск, 18-23

ПЕчЕНкинА 2006: Печенкина, О.А. Этика симулякров Ж. Бодрийяра (анализ постмодернистской рецепции этического). Автореф. дис. ... канд. философ. наук. Тула.

РАДищЕВ 2001: Радищев, А.Н. О человеке, его смертности и бессмертии. Санкт-Петербург.; Москва; Харьков; Минск: Питер.

СоловьЕВ 2002: Соловьев, В.С. Понятие о Боге (В защиту философии Спинозы) // Спиноза: pro et contra. Санкт-Петербург. 132-156.

СпинОзА 1991: Спиноза. Богословско-политический трактат // Человек: Мыслители прошлого и настоящего о его жизни, смерти и бессмертии. Древний мир - эпоха Просвещения. Москва: Политиздат, 293-295. (пер. с лат. Лопаткина, М.)

СпинОзА 1998а: Спиноза. Краткий трактат о Боге, человеке и его счастье // Спиноза. Избранные произведения. Ростов-на-Дону: Феникс, 23-132. (пер. с голланд. под редакцией Рубина, А.И.)

СпинОзА 1998б: Спиноза. Трактат об усовершенствовании разума // Спиноза. Избранные произведения. Ростов-на-Дону: Феникс, 281-324. (пер. с лат. Воровскоий Я.М.) 
ФЛОРЕНСКИЙ 2000: священник Флоренский П.А. Иконостас // священник Флоренский П.А. Иконостас. Избранные труды по искусству. Санкт-Петербург: МИФРИЛ; Русская книга, 1-173.

ХАБЕРМАС 2005: Хабермас, Ю. Модерн - незавершенный проект // Вопросы философии. 1992. №4. (пер. с нем. Скуратова, Б.М.)

ХАБЕРМАС 2008: Хабермас, Ю. Философский дискурс о модерне. 2-е изд. Москва. (пер. с нем. Беляева, М.М. и др.)

ШЕЛЕР 1994: Шелер, М. Спиноза // Шелер М. Избранные произведения. Москва: Гнозис, С.57-69. (пер. с нем. Малинкина, А.Н.)

ШЕСтов 1990: Шестов, Л.И. На весах Иова (Странствования по душам) // Шестов Л.И. Соч.: в 2 тт. Москва: Наука, Т.2. 7-350.

Шульц 2018: Шульц, С.А. Рим Стендаля, Гоголя и Феллини // Творчество Гоголя в контексте европейских культур. Взгляд из Рима. Семнадцатые Гоголевские чтения. МОСКВА; Новосибирск, 83-88.

SPIEKER 1999: Sven Spieker (Ed.) Gøgøl: Exploring Absence: Negativity In $19^{\text {th }}$ Century Russian Literature. Bloomington, Indiana University, Slavica.

Сергей Шульц

независимый исследователь

Ростов-на-Дону, Россия

s_shulz@mail.ru; shulcz-70@mail.ru 